\title{
Fungsi Leadership dalam Pengelolaan Lembaga Pendidikan Islam
}

\author{
Nur Fauziah \\ Sekolah Pascasarjana, UIN Syarif Hidayatullah Jakarta, Indonesia \\ nur.fauziah19@mhs.uinjkt.ac.id
}

\begin{abstract}
Abstrak:
Artikel ini bertujuan untuk mengetahui fungsi leadership dalam pengelolaan lembaga pendidikan Islam. Adapun pendekatan yang digunakan dalam tulisan ini adalah pendekatan kualitatif dengan menggunakan metode deskriptif analisis dan merupakan penelitan kepustakaan (library research). Leadership (kepemimpinan) merupakan salah satu faktor yang menentukan pencapaian visi, misi, dan tujuan dari suatu lembaga atau organisasi. Dalam konteks lembaga pendidikan Islam, salah satu faktor kunci keberhasilan pengelolaan lembaga pendidikan Islam adalah kepemimpinan kepala sekolah/madrasah, pengasuh pesantren, dekan, rector, dan seluruh elemen pendidikan Islam juga sangat berpengaruh dalam keberhasilan Pendidikan Islam.
\end{abstract}

Kata Kunci: Leadership, Fungsi Leadership, Lembaga Pendidikan Islam.

\begin{abstract}
:
This article aims to look at the leadership function in Islamic educational institutions. The approach used in this paper is a qualitative approach using descriptive analysis and is library research (library research). Leadership is one of the factors that determine the vision, mission, and goals of an institution or organization. In the context of Islamic education institutions, one of the factors in the management of Islamic education institutions is the leadership of the school/madrasah principals, pesantren caregivers, deans, chancellors, and all elements of Islamic education are also very influential in their confidence in Islamic education.
\end{abstract}

Keywords: Leadership, Leadership Function, Islamic Educational Institutions. 


\section{Pendahuluan}

Manusia pada hakikatnya mempunyai dua kapasitas. Baik dipandang sebagai makhluk individu maupun makhluk sosial. Manusia mempunyai kemampuan dan kebebasan untuk berfikir, memilih jalan hidup dan mandiri, sehingga manusia disebut makhluk individu. Selanjutnya, keberadaan orang lain dalam kehidupan seseorang sangatlah diperlukan, hal ini dikarenakan manusia sebagai makhluk sosial. ${ }^{1}$

Kehidupan manusia memang tidak dapat dipisahkan satu sama lain. Interaksi sosial antar individu seringkali menimbulkan motivasi untuk hidup berdampingan dan membentuk suatu kelompok. Dalam rangka meraih tujuannya, manusia membutuhkan support dan bantuan dari orang lain. Kemudian bekerja sama berdasarkan pada kesamaan kepentingan kebutuhan kolektif yang telah dirumuskan. ${ }^{2}$

Disadari atau tidak, konsep leadership sudah ada sejak manusia lahir ke dunia. Dalam kehidupan manusia ada orang yang mengatur, memimpin, mengarahkan, dan memotivasi manusia untuk melakukan kegiatan agar mencapai suatu tujuan. Manusia ynang pandai mengatur, memimpin, mengarahkan dan memotivasi tersebut disebut sebagai seorang leader. Sedangkan proses mengatur memimpin mengarahkan dan memotivasi disebut dengan istilah leadership atau kepemimpinan. ${ }^{3}$

Leadership sangat diperlukan dalam setiap Aktivitas kehidupan manusia dimanapun berada. Baik dalam organisasi skala kecil maupun besar. Organisasi pemerintah maupun swasta. Bahkan dalam organisasi skala global maupun internasional. Tidak dapat dibayangkan apabila tidak ada leader atau leadership dalam kehidupan manusia maka tidak ada orang yang mengatur, memimpin, mengarahkan, memotivasi, dan bahkan tidak ada orang yang bertanggung jawab dalam suatu kelompok manusia (masyarakat) ataupun organisasi tertentu sudah pasti akan terdapat kekacauan ketidakteraturan dan ketidaktertiban. Untuk itulah, leadership sangat diperlukan dalam kehidupan masyarakat maupun organisasi. ${ }^{4}$

Kemudian, agar kerjasama berjalan sebagai mana mestinya, maka dibutuhkan adanya seorang pemimpin yang mampu melakukan optimalisasi peran demi pencapaian tujuan.

\footnotetext{
${ }^{1}$ M. Chazienul Ulum, Leadership Dinamika Teori Pendekatan dan Isu Strategis Kepemimpinan di Sektor Public, (Malang: Universitas Brawijaya Press, 2012), 1.

${ }^{2}$ M. Chazienul Ulum, Leadership Dinamika Teori Pendekatan dan Isu Strategis Kepemimpinan di Sektor Public, 1. 2020), 77

${ }^{3}$ Syafrida Hafni Sahir, et.all, Keterampilan Manajerial Efektif, (Sumatera Utara: Yayasan Kita Menulis,

${ }^{4}$ Syafrida Hafni Sahir, et.all, Keterampilan Manajerial Efektif, 77.

246 | IQ (Ilmu Al-qur'an): Jurnal Pendidikan Islam | Volume 3 No.02 2020
} 
Misalnya, dalam pengelolaan lembaga pendidikan Islam. Kepemimpinan kepala sekolah/madrasah merupakan salah satu kunci keberhasilan pengelolaan lembaga pendidikan Islam. Tulisan ini akan menguraikan "Fungsi Leadership dalam Pengelolaan Lembaga Pendidikan Islam".

\section{Pengertian Leader (Leadership) dan Manajemen (Manajerialship)}

Leadership (Kepemimpinan) berasal dari kata "lead" dan "leader" berarti memimpin dan pemimpin. Lead adalah memimpin, mengarahkan, dan menggerakkan. Sedangkan leader adalah setiap orang yang dapat menjalankan leadership..$^{5}$ istilah kepemimpinan berasal dari kata "pimpin" yang artinya bimbing atau tuntun. Dari kata pimpin tersebut maka lahirlah kata kerja "memimpin" yang artinya membimbing dan menuntun. ${ }^{6}$

Selanjutnya, Manajemen berasala dari kata "managio" artinya pengurusan atau "managiare" yang berarti melatih dan mengatur langkah-langkah. Manajemen juga sering diartikan sebagai ilmu, kiat dan profesi. ${ }^{7}$

Menurut Cuban, "leadership with change while management is seen as a maintenance activity”. Kepemimpinan merupakan perubahan. Sedangkan manajemen dipandang sebagai aktivitas pemeliharaan. Jadi yang dimaksud dengan kepemimpinan (leadership) adalah kegiatan mempengaruhi tingkah laku seseorang agar apa yang dicita-citakannya dapat tercapai. Sedangkan menejemen merupakan kegiatan yang dilakukaan untuk mempertahankan suatu organisasi secara efisien dan efektif. Meskipun menejemen sering kali menunjukkan keterampilan dalam kepemimpinan, fungsi keseluruhannya mengarah pada pemeliharaan dari pada perubahan. ${ }^{8}$

Dalam school leadership concepts and evidence yang ditulis oleh Tony Bush dan Derek Glover, tidak ada yang disepakati tentang konsep kepemimpinan. Lebih dari 350 definisi kepemimpinan yang dikemukakan para ahli, akan tetapi tidak ada yang jelas dan tegas apa yang membedakan pemimpin dan non pemimpin. Namun mengingat kepemimpinan diterima secara luas untuk efektifitas dan perbaikan sekolah, maka hal yang sangat penting untuk menetapkan

${ }^{5}$ Syafrida Hafni Sahir, et.all, Keterampilan Manajerial Efektif, 78.

${ }^{6}$ Imam Machali, Kepemimpinan Pendidikan dan Pembangunan Karakter, (Yogyakarta: Pedagogia, 2012), 1.

${ }^{7}$ Asnawir, Manajemen Pendidikan, (Padang: IAIN IB Press, 2006), 25.

${ }^{8}$ Cuban L, The Managerial Imperative and the Practice of Leadership in Schools, Albany, (NY: State University of New York Press, 1899) 
konsep kepemimpinan. Elemen utama yang banyak mendefinisikan kepemimpinan adalah "proses pengaruh". 9

Tony Bush berpendapat bahwa "Leadership can be understood as a process of influence based on clear values and beliefs and leading to a 'vision' for the school. The vision is articulated by leaders who seek to gain the commitment of staff and stakeholders to the ideal of a better future for the school, its learners and stakeholders". Kepemimpinan merupakan suatu kegiatan yang dilakukan untuk mempengaruhi seseorang berdasarkan nilai-nilai dan keyakinan yang jelas dan bertujuan untuk fokus terhadap visi sekolah. Visi tersebut digambarkan sebagai usaha untuk memperoleh kepercayaan pengikut dan pemangku kepentingan yang dilakukan oleh pemimpin terhadap apa yang dicita-citaan untuk meraih masa depan yang cemerlang agar sekolah, peserta didik, dan pemangku kepentingan menjadi lebih baik. $^{10}$

Syafrida, dkk juga berpendapat bahwa leadership merupakan proses kegiatan yang dilakukan seseorang untuk mengatur, mengarahkan, menggerakkan, mempengaruhi, memotivasi, dan memimpin orang lain, untuk mengikuti apa yang menjadi keinginannya agar tercapai tujuan yang diharapkan. ${ }^{11}$

Pemimpin merupakan figure pertama yang mengambil inisiatif perubahan dan mengkomunikasikannya kepada para pengikut untuk mendapatkan respons yang positif (baik dalam hal perilaku maupun kinerja). Pengikut tersebut merupakan aktor yang melakukan hal yang sama (melakukan perubahan) untuk mencapai tujuan meskipun dengan peran yang berbeda. Dalam konteks tersebut Ulum mengemukakan bahwa leadership merupakan kegiatan yang dilakukan seseorang terhadap individu atau kelompok dalam suatu organisasi agar dapat bergotong royong dalam mencapai keberhasilan yang dituju dengan cara mempengaruhi, mengarahkan dan menggerakkan. ${ }^{12}$

Seorang pemimpin dituntut dapat membawa organisasi berkembang dari waktu ke waktu. Mulai dari merencanakan strategi berbasiskan potensi dan sumber daya yang ada. Kemudian mengerahkan, mengarahkan, memantau, dan mengevaluasi. Dalam arti luas, itulah pemimpin stategis, yakni seseorang yang dapat memimpin dan memanfaatkan sumber daya

\footnotetext{
${ }^{9}$ Tony Bush dan Derek Glover, School Leadership Concepts and Evidence, (Spring: National College for School Leadership, 2003), 4.

${ }^{10}$ Tony Bush, Educational leadership and management: theory, policy, and practice, South African Journal of Education EASA Vol 27(3) 2007, 391-406, 403.

${ }^{11}$ Syafrida Hafni Sahir, et.all, Keterampilan Manajerial Efektif, 78.

${ }^{12}$ M. Chazienul Ulum, Leadership Dinamika Teori Pendekatan dan Isu Strategis Kepemimpinan di Sektor Public, 2.

248 | IQ (Ilmu Al-qur'an): Jurnal Pendidikan Islam| Volume 3 No.02 2020
} 
yang ada. Pemimpin seperti ini memulai dari visi, mengubah, dan menggerakkan pengikut agar mencapai tujuan organisasi. Dengan demikian, pemimpin diharapkan dapat menggerakkan organisasi. Selain itu, pemimpin harus mempunyai anak buah baru atau pengikut yang kompeten dan satu visi dengannya. ${ }^{13}$

Dengan demikian, kepemimpinan (leadership) merupakan kegiatan mengerahkan segala kemampuan secara bersama-sama dengan bantuan dari segala unsur-unsur yang terdapat dalam suatu oganisasi. Unsur tersebut terbagi menjadi dua unsur yaitu human resource dan non human resaouces. Oleh karena itu, lembaga pendidikan Islam merupakan lembaga organisasi yang terdiri dari berbagai karakteristik. Karakteristik terpenting terdapat pada sumber daya manusia $^{14}$

Jika dikaitkan dengan pengelola lembaga pendidikan islam, maka leadership yang dimaksud adalah Dirjen Pendidikan Islam yang mempunyai kepemimpinan atau wewenang dalam merencanakan, mengatur, mengontrol, mengarahkan, mengawasi, memimpin, memotivasi, mempengaruhi, dan memberikan evaluasi serta penilaian terhadap pengikut yang mempunyai tujuan sama dalam memajukan lembaga pendidikan Islam yang dikelolanya. Sedangkan kepala sekolah/madrasah, pengasuh pesantren, dekan, rektor merupakan manager.

\section{Perbedaan Leader dan Manager}

Lemmer menjelaskan perbedaan antara menejemen dan kepemimpinan (leadership). Menurut Lemmer, istilah menejemen dan leadership kadang kala disebut sebagai dua konsep yang sama padahal menejemen berbeda dengan kepemimpinan seperti halnya siang dan malam. ${ }^{15}$ Keduanya merupakan pendekatan yang penting terhadap penelitian, analisis, pemecahan masalah menejemen dan kepemimpinan pada organisasi bisnis dan non bisnis, organisasi pemerintah dan non pemerintah maupun organisasi kemasyarakatan. ${ }^{16}$

Clemmer berpendapat bahwa terdapat perbedaan utama antara manajemen dan kepemimpinan. Manajemen berarti mengelola berbagai hal sedangkan kepemimpinan adalah memimpin orang lain. Meskipun terdapat perbedaan antara kepemimpinan dan manajemen, akan tetapi keduanya memiliki kekuatan yang saling melengkapi. ${ }^{17}$

\footnotetext{
${ }^{13}$ AB. Susanto, Stretegic Leadership, (Jakarta: Gramedia Pustaka Utama, 2019), 2-3.

${ }^{14}$ Elvi Rahmi, Leadership-Manajerialship dalam Pendidikan Islam, Jurnal Tadris, Volume. 13, Nomor 2, Desember 2018, 219.

${ }^{15}$ Roger Powley and Cindy Edwards, Principles of Managmen, Commonwealth of Learning Edition 1.0, (Burnby: British Columbia, 2012), 12.

${ }^{16}$ Syaiful Sagala, Pendekatan dan Model Kepemimpinan, (Jakarta: Prenada Media, 2018), h. 319. 12.

${ }^{17}$ Roger Powley and Cindy Edwards, Principles of Managmen, Commonwealth of Learning Edition 1.0,
} 
Tabel 1 Kekuatan saling melengkapi

\begin{tabular}{|c|c|}
\hline Management & Leadership \\
\hline Processes & People \\
\hline Fact & Feeling \\
\hline Intellectual & Emotional \\
\hline Head & Heart \\
\hline Position & Persuasion Power \\
\hline Power Control & Possibility Thinking \\
\hline Problem Solving & Proactive \\
\hline Reactive & Doing the Right Things \\
\hline Doing Things Right & Values \\
\hline Rules & Vision \\
\hline Goals & Stroke the Fire within People \\
\hline Like a Fire under People & Verbal Communication \\
\hline Written Communication & Innovation \\
\hline Standarization &
\end{tabular}

Manager merupakan pimpinan. Pimpinan/manajer adalah seseorang yang diangkat berdasarkan pengangkatan atau surat keputusan (SK) tertentu. Sedangkan leader/pemimpin belum tentu diangkat berdasarkan surat keputusan (SK), akan tetapi bisa saja diangkat berdasarkan pengakuan follower atau pengikut atau bawahannya. Leader dapat bersifat formal yang terdapat dalam suatu organisasi formal dan juga dapat bersifat informal dalam suatu organisasi informal pula. Pimpinan atau manajer yang diangkat berdasarkan surat keputusan (SK) akan lebih baik apabila dapat menjalankan perannya sebagai leader atau pemimpin sehingga follower atau bawahan akan lebih semangat dan termotivasi dalam bekerja. ${ }^{18}$

Sementara itu, leadership tidak selalu terkait dengan suatu organisasi tertentu. Akan tetapi, leadership dapat diaplikasikan dimana saja, yang terpenting adalah seseorang dapat mengimplementasikan kemampuannya dalam mempengaruhi seseorang untuk mencapai tujuan yang diinginkan. Sedangkan pimpinan (manajemen) memerlukan bantuan dari berbagai unsur yang bersifat potensial baik manusia maupun selain manusia untuk menyusun suatu organisasi yang telah ditentukan. Jadi harus ada keterkaitan antara manajemen dan

${ }^{18}$ Syafrida Hafni Sahir, et.all, Keterampilan Manajerial Efektif, 78. 
kepemimpinan agar tercapai apa yang menjadi tujuan sebuah organisasi dan terlaksana dengan baik. ${ }^{19}$ Pendapat tersebut, diperkuat oleh Robins \& Decenzo yang menjelaskan bahwa manajemen mengacu pada proses menyelesaikan sesuatu secara cepat dan tepat. Begitupun Hammond yang bermaksud menjelaskan bahwa manajemen menggambarkan semua aktivitas yang terlibat dalam organisasi sumber daya (orang, keuangan, peralatan, dan bahan) yang dibutuhkan untuk mencapai tujuan. ${ }^{20}$

Kegiatan yang biasa dilakukan dalam suatu organisasi untuk menyelesaikan suatu pekerjaan secara efektif dan efisian melalui bantuan orang lain disebut dengan manajemen. Sedangkan kepemimpinan terjadi ketika seseorang dapat mempengaruhi orang lain atau sekelompok orang demi tercapainya perubahan yang diinginkan. Leader dan manajemen sangatlah erat kaitannya, disebabkan karena leader mempunyai posisi yang sangat sentral dalam manajemen sedangkan perilaku leader merupakan perilaku yang sangat penting dari perilaku manajemen. Membuat kebijakan merupakan tugas utama dari kepemimpnan. Kepemimpinan dapat berlangsung dengan baik jika ada keputusan mengenai kebijakan yang akan dijalankan, begitupun dengan manajemen. Berangkat dari pemaparan tersebut dapat dipahami bahwa kepemimpinan yang dimiliki oleh pemimpin yang memiliki jiwa kepemimpinan yang baik akan menghantarkan manajemen dalam mencapai tujuan. ${ }^{21}$

Seorang manajer yang efektif tentulah seorang pemimpin yang efektif. memimpin adalah fungsi pokok seorang manajer. Akan tetapi sebenarnya lebih banyak harus dilakukan seorang manajer bukan hanya memimpin. Perintah arahan dan ide seorang pemimpin akan diikuti oleh anggotanya disebabkan seorang pemimpin itu memiliki kekuasaan atas jabatan yang melekat pada dirinya, jabatan sebagai sumber kekuasaan bagi seorang tidak cukup untuk memberi keberhasilan bisnis yang dikelolanya bagi seorang pemimpin meskipun telah menduduki jabatan masih diperlukan keterampilan memimpin dan membangkitkan semangat anggota organisasi untuk melakukan kegiatan dengan penuh dedikasi yang tinggi. ${ }^{22}$

Hersey dan blanchard dalam Sagala memandang ada perbedaan penting antara dua konsep manajemen dan kepemimpinan esensi konsep kepemimpinan lebih luas dari konsep manajemen dan tanggung jawab pemimpin lebih besar daripada tanggung jawab manajer. Oleh karena itu, manajemen merupakan kepemimpinan yang mempunyai ciri khas dan dipandang

\footnotetext{
${ }^{19}$ Elvi Rahmi, Leadership-Manajerialship dalam Pendidikan Islam, Jurnal Tadris, Volume. 13, Nomor 2, Desember 2018, 241

${ }^{20}$ Roger Powley and Cindy Edwards, Principles of Managmen, Commonwealth of Learning Edition 1.0, (Burnaby: British Columbia, 2012), 7.

${ }^{21}$ Elvi Rahmi, Leadership-Manajerialship dalam Pendidikan Islam, Jurnal Tadris, Volume. 13, Nomor 2, Desember 2018, 220

${ }^{22}$ Syaiful Sagala, Pendekatan dan Model Kepemimpinan, (Jakarta: Prenada Media, 2018), 319.
} 
sebagai suatu jenis khusus kepemimpinan dimana pencapaian tujuan organisasi merupakan hal yang terpenting dan perbedaan yang paling utama ada pada istilah organisasi. ${ }^{23}$

Pemimpin dan kepemimpinan menurut Kartono dalam Sagala sangat berhubungan dengan upaya yang dilakukan manajemen dan menjadi hal yang paling terpenting dari manajemen organisasi dan manajemen administrasi. Manajemen berfungsi untuk melakukan perencanaan, pengorganisasian, pengarahan, pengawasan, evaluasi, dan penilaian menjadi persyaratan utama yang harus dikuasai dengan efektif dan efisien oleh setiap pemimpin. Kemampuan dan keterampilan kepemimpinan atau leadership maupun seni memimpin pada dasarnya untuk mengarahkan dan memecahkan masalah organisasi dan mencapai tujuan secara efektif. Kemampuan dan keterampilan memimpin merupakan faktor penting dalam efektivitas manajer pada suatu sistem manajemen dalam organisasi. ${ }^{24}$

Selain itu, fungsi manajemen menurut para ahli terdapat perbedaan pendapat. Henri Fayol (1841-1925) sering digambarkan sebagai bapak dari manajemen modern. Henri Fayol pernah menjadi direktur pelaksana sebuah perusahaan pertambangan Prancis yang besar, dan lebih memperhatikan efisiensi organisasi. Berdasarkan pengalamannya keberhasilan dibidang organisasi, Henri Fayol mengembangkan teori umum administrasi bisnis dan merupakan orang yang pertama kali memecah manajemen menjadi lima elemen berbeda. Yaitu: perencanaan, pengorganisasian, penguasaan, pengkoordinasian, dan pengendalian. Atas dasar lima elemen manajemen, Fayol kemudian mulai mengidentifikasi apa yang disajikan sebagai 14 prinsip untuk meningkatkan efektivitas manajerial.

Menariknya, prinsip-prinsip Fayol memiliki banyak kesamaan dengan tulisan Lyndall Urwick (1891-1983), seorang perwira militer yang menjadi konsultan manajemen, yang menggabungkan ide-ide manajemen ilmiah dan teori organisasi klasik ke dalam satu pandangan manajemen. Seperti Fayol, Lyndall Urwick menyebutkan bahwa elemen manajemen terdiri atas lima dasar, yaitu: perencanaan, pengorganisasian, penguasaan, pengkoordinasian, dan pengendalian. ${ }^{25}$

Berbeda dengan Henri Fayol dan Lyndall Urwick, George.R.Terry berpendapat bahwa manajemen memiliki fungsi sebagai perencanaan, pengorganisasian, penggerak, dan pengendalian. ${ }^{26}$

${ }^{23}$ Syaiful Sagala, Pendekatan dan Model Kepemimpinan, 320.

${ }^{24}$ Syaiful Sagala, Pendekatan dan Model Kepemimpinan, 320.

${ }^{25}$ Roger Powley and Cindy Edwards, Principles of Managmen, Commonwealth of Learning Edition 1.0, 9.

${ }^{26}$ George R Terry, Prinsip-Prinsip Manajemen, (Jakarta : Bumi Aksara, 2012).

252 | IQ (Ilmu Al-qur'an): Jurnal Pendidikan Islam| Volume 3 No.02 2020 
Sejalan dengan studi Robbins dan coulter dalam Sagala yang berpendapat bahwa leader yaitu seseorang yang mempunyai kemempuan dalam mempengaruhi orang lain dan mempunyai kewenangan terhadap manajerial. Idealnya setiap manajer harus menjadi pemimpin dan manajer akan efektif bilamana memiliki keterampilan cara membangun kepercayaan, menganalisis situasi, modifikasi keadaan supaya selaras dengan caranya memimpin dan dapat mengevaluasi perilaku pemimpin atau manajer yang lebih baik dalam keadaan tertentu untuk mencapai tujuan dan sasaran. ${ }^{27}$

Dengan demikian dapat disumpulkan bahwa terletak perbedaan antara pemimpin dan manajer. Namun tugas mereka seringkali sama. Ada masanya pemimpin bertindak sebagai manajer dan ada masanya manajer bertindak sebagai pemimpin. Akan tetapi fakta menunjukan bahwa dalam suatu organisasi butuh pemimpin dan manajer. Istilah pemimpin digunakan pada tataran organisasi sedangkan manajer pada tataran unit organisasinya. Masing-masing melakukan pemantauan berkesinambungan sesuai otoritas dan wewenang yang dimilikinya dalam organisasi untuk efektifitas meraih tujuan.

Selain itu, kepemimpinan tidak selalu berkaitan dengan suatu organisasi tertentu, akan tetapi kepemimpinan dapat berlangsung dimanapun dan kapanpun, dengan ketentuan seseorang harus mampu mempengaruhi orang lain agar mencapai tujuan yang diingikan. Sedangkan manajemen merupakan proses pengelolaan terhadap suatu organisasi tertentu. Jadi antara manajemen dan kepemimpinan harus saling berhubungan satu sama lain agar tercipta tujuan organisasi yang diinginkan secara efektif dan efisien.

\section{Fungsi Leadership dalam Pengelolaan Lembaga Pendidikan}

John C. Maxwell menjelaskan bahwa tugas leader yaitu "a leader is one who knows the way, goes the way, and shows the way". Pemimpin membebaskan pengikutnya untuk menjadi diri sendiri tanpa adanya paksaan untuk menjadi seperti dirinya. Pemimpin hanya menunjukan jalan, setelah itu setiap orang harus memilih untuk melakukan dengan caranya masingmasing. ${ }^{28}$

Kepemimpinan merupakan penggerak kemajuan pada suatu organisasi maupun lembaga. Kepemimpinan yang bermutu akan mengarahkan lembaga atau organisasi menuju keberhasilan. Oleh sebab itu, seorang pemimpin harus mampu mengembangkan, mengatur dan menjalankan sebuah organisasi secara terampil dan cermat. Oleh karena itu, tugas seorang

27 Syaiful Sagala, Pendekatan dan Model Kepemimpinan, 320.

28 Riswan E. Tarigan, 2018, diakses dari https://huxleyi.wordpress.com/2018/12/07/brainy-quote-aleader-is-one-who-knows-the-way-goes-the-way-and-shows-the-way-john-c-maxwell-001/ 
pemimpin tidak hanya mengambil kebijakan lebih dari itu sebagai kiat untuk mencapai kesuksesan dalam sebuah lembaga atau organisasi. Atau dengan kata lain kepemimpinan kemampuan meyakinkan orang lain agar mau bekerja sama di bawah pimpinannya sebagai sebuah tim untuk mencapai tujuan tertentu. ${ }^{29}$

Dalam lembaga pendidikan Islam, pemimpin memiliki kedudukan yang sangat strategis dalam merealisasikan visi organisasi terutama dalam mengembangkan kualitas kelembagaan, meningkatkan sumber daya manusia (SDM), dan daya saing dalam berbagai bidang. Dengan demikian, pemimpin harus berperan aktif. Sehubungan dengan hal tersebut, peran kepemimpinan tidak hanya menjalankan peran secara sistematis akan tetapi harus menjadikan tujuan sebagai sesuatu yang nyata. ${ }^{30}$

Sebagai suatu contoh, leadership dalam pengelolaan lembaga pendidikan Islam adalah kepala sekolah/madrasah. Kepala sekolah/madrasah merupakan salah satu komponen pendidikan yang sangat berdampak terhadap keberhasilan suatu lembaga pendidikan Islam. Eksistensi kepala sekolah/madrasah menjadi suatu tokoh yang sangat fundamental untuk dapat mengubah sekolah/madrasah menjadi unggul bahkan sebaliknya dari waktu ke waktu.

Eksistensi kepala sekolah/madrasah sebagai lembaga organisasi tidak hanya sekedar menjadi seorang leader, akan tetapi lebih dari itu kepala sekolah/madrasah juga berfungsi sebagai akumulator, konseptor, serta manajer. Pada tahap ini, peran kepala sekolah tidak hanya menjelaskan fungsi sebagai seorang yang dapat memobilisasi, mengaruhi, dan menuntut bawahannya untuk melakukan tugas organisasi namun harus bisa melaksanakan kewajiban serta dapat berpartisipasi terhadap efektivitas dan efisiensi. Tujuannya untuk kelangsungan pendidikan.

Menurut Kebijakan Pendidikan nasional yang berlaku saat ini, ada tujuh fungsi kepala sekolah/madrasah (leadership) dalam pengelolaan Lembaga Pendidikan Islam, yaitu:

\section{Kepala sekolah/madrasah sebagai educator (pendidik)}

Menurut kerangka pembelajaran, kepala sekolah/madrasah harus berpusat pada pengembangan kurikulum dan pembelajaran yang merupakan faktor utama dari sistem pendidikan Islam. Selain itu, kepala sekolah/madrasah harus memberikan dorongan semangat

29 Nur Ita A'ini Qudwatal Millah, dan Far'ia. 2020. "Kepemimpinan Spiritual Dalam Lembaga Pendidikan: Analisis Maqasid Syariah”. Ilmu Al-Qur'an (IQ): Jurnal Pendidikan Islam 3 (01), 106 https://doi.org/10.37542/iq.v3i01.56

30 Djunawir Syafar, Teori Kepemimpinan dalam Lembaga Pendidikan Islam, TADBIR : Jurnal Manajemen Pendidikan Islam, Volume 5, Nomor 1 : Februari 2017, 147-148

254 | IQ (Ilmu Al-qur'an): Jurnal Pendidikan Islam| Volume 3 No.02 2020 
serta memfasilitasi guru untuk meningkatkan kompetensi yang dimilikinya dalam rangka memberikan pilihan terhadap aktifitas kegiatan pembelajaran yang efektif dan efisien. ${ }^{31}$

Kepemimpinan yang bertujuan pada peningkatan kualitas pembelajaran merupakan kepemimpinan pembelajaran. Dalam mengimplementasikan kepemimpinan pembelajaran, kepala sekolah akan meluangkan banyak waktunya untuk memperbaiki dan mengembangkan kualitas pembelajaran. Aktivitas yang dikerjakan diantaranya mengarah kepada pembaruan dan pengembangan kuriukulum, PBM, mengevaluasi dan mengembangkan kinerja guru, memberikan fasilitas serta membantu guru dan siswa dengan baik, mengembangkan budaya yang dapat mendukung bagi pembelajaran, serta melakukan sinkronisasi dengan guru, siswa dan orang tua dalam upaya perbaikan kualitas pembelajaran. ${ }^{32}$

\section{Kepala sekolah/madrasah sebagai manajer}

Kepala sekolah/madrasah sebagai manajer, harus melakukan kegiatan pemeliharaan dan pengembangan profesi para guru. Kepala sekolah/madrasah harus memberikan fasilitas dan kesempatan yang memadai terhadap para guru agar dapat menjalankan aktifitas pengembangan profesi melalui berbagai aktifitas pendidikan dan pelatihan baik yang dilaksanakan di sekolah/madrasah maupun di luar sekolah/madrasah, seperti memberikan kesempatan guru untuk melanjutkan Pendidikan ke jenjang yang lebih tinggi atau memberikan kesempatan guru untuk mengikuti berbagai pelatihan yang diselenggarakan oleh sekolah maupun pihak lain. ${ }^{33}$

Selain itu, kepala sekolah/madrasah sebagai manajer harus memiliki kemampuan mengorganisasikan secara perorangan dengan menjabarkan tugas apa saja yang dilakukan yang sesuai dengan apa yang telah ditetapkan, memiliki kemampuan memobilisasi para guru dan segala sumber daya yang ada serta lebih lanjut memberikan model teladan yang dinamis dalam kegiatan rutin dan temporer, serta mempunyai kemampuan menyusun program secara sistematis. ${ }^{34}$

Kepala sekolah/madrasah sebagai administrator

\footnotetext{
${ }^{31}$ Hendarman, Revolusi Kinerja Kepala Sekolah, Cet.7, (Jakarta: Indeks, 2019), 18

32 Endang Herawan, Kinerja Kepala Sekolah Sebagai Instructional Leader, Pedagogia Jurnal Ilmu Pendidikan, 264

${ }^{33}$ Hendarman dan Rohanim, Kepala Sekolah segabai Manajer Teori dan Praktik, (Bandung: PT. Remaja Rosdakarya, 2019), 42

34 Triyo Suppriyatno Marno, Manajemen dan Kepemimpinan Pendidikan Islam, (Bandung: Refika Aditma, 2008), 39
} 
Kepala sekolah/madrasah harus mendayagunakan dan memberdayakan guru dan staff yang ada agar kegiatan yang diadakan dapat berjalan secara efektif dan efisien untuk menggapai visi dan misi sekolah/madrasah. Kepala sekolah/madrasah berkewajiban untuk mengadakan kegiatan pendidikan yang mempunyai arah dan tujuan yang jelas, karena kepala sekolah/madrasah merupakan garda terdepan dalam pencapaian tujuan pendidikan. Pada intinya, terdapat tujuh kegiatan pokok yang harus diemban kepala sekolah, yaitu: merencanakan, mengorganisasi, mengadakan staf mengarahkan/orientasi sasaran, mengkoordinasi, memantau serta menilai/evaluasi. ${ }^{35}$

Kepala sekolah/madrasah harus mempunyai kemampuan untuk menjalankan semua instrument KBM secara komplit yang dibuktikan dengan data administrasi yang akurat. Serta mampu mengelola administrasi kesiswaan, ketenagaan, keuangan, sarana dan prasarana, dan administrasi persuratan dengan ketentuan yang berlaku. ${ }^{36}$

\section{Kepala sekolah/madrasah sebagai supervisor}

Kehadiran guru, kepala sekolah yang berkualitas, professional, sejahtera, dan bermartabat, merupakan salah satu faktor penting yang harus di penuhi agar pendidikan berkualitas. ${ }^{37}$ Kepala sekolah sebagai pemimpin pendidikan memiliki banyak peran, diantaranya sebagai educator, manajer, dan administrator, ia juga sebagai sepervisor. Sebagai supervisor, kepala sekolah mempunyai fungsi untuk membina sekolahnya agar berhasil mencapai tujuan pendidikan yang diharapkan.

Tujuan pendidikan akan tercapai jika kepala sekolah sebagai supervisor memiliki kemampuan untuk menghadirkan keadaan belajar mengajar yang menyenangkan. Kepala sekolah berkewajiban untuk melakukan pembinaan terhadap guru secara berkala. Hal ini disebabkan karena aktifitas kepala sekolah dan guru berlangsung di sekolah secara bersamaan dan menuntut adanya kerjasama antara guru dan kepala sekolah. Sehingga, kepala sekolah bertanggung jawab penuh terhadap penyelenggaraan pendidikan dan akademik di sekolah berjalan dengan lancar. ${ }^{38}$

\footnotetext{
${ }^{35}$ Hendarman dan Rohanim, Kepala Sekolah segabai Manajer Teori dan Praktik, (Bandung: PT. Remaja Rosdakarya, 2019), 43

${ }^{36}$ Triyo Suppriyatno Marno, Manajemen dan Kepemimpinan Pendidikan Islam, 39

${ }^{37}$ Mulyasa, E, Menjadi Guru Profesional Menciptakan Pembelajaran Kreatif dan Menyenangkan, (Bandung: PT Remaja Rosdakarya, 2009), 4-6

${ }^{38}$ Sepriadi dan Syarwani Ahmad, Pengaruh Peran Kepala Sekolah sebagai Supervisor Akademik Terhadap Kinerja Guru di SMK PGRI Tanjung Raja, Jurnal Manajemen, Kepemimpinan, dan Supervisi Pendidikan, Volume 2, No. 1, Januari-Juni 2017, 55

256 | IQ (Ilmu Al-qur'an): Jurnal Pendidikan Islam| Volume 3 No.02 2020
} 
Kepala sekolah berkewajiban untuk menyelenggarakan aktifitas pendidikan. Oleh sebab itu, kepala sekolah memiliki kewajiban untuk selalu mengadakan pembinaan dalam arti berusaha agar pengelolaan, penilaian, bimbingan, pengawasan, pengendalian, dan pengembangan pendidikan dapat berjalan dengan efektif dan efisien. ${ }^{39}$ Sehingga, pelaksanaan aktifitas pendidikan dapat diawasi dan terarah pada tujuan yang dicita-citakan. Pengawasan dan pengendalian juga merupakan tindakan preventiv untuk mencegah agar para tenaga kependidikan tetap berada di jalan kebenaran agar terhindar dari suatu hal yang tidak diinginkan serta lebih berhati-hati dalam menjalankan kewajibannya. ${ }^{40}$

Selain itu, tugas kepala sekolah sebagai supervisor yaitu menyelenggarakan kurikulum yang berlangsung di sekolah agar mendapatkan hasil yang sesuai apa yang telah ditentukan. Aspek-aspek kurikulum yang harus dimiliki oleh supervisor adalah materi pelajaran, proses belajar mengajar, evaluasi kurikulum, dan pengembangan kurikulum.

Sebagai supervisor, terdapat beberapa peran penting yang harus dimiliki kepala sekolah, yaitu: melaksanakan penelitian yang bersifat sederhana untuk memperbaiki keadaan dalam proses pembelajaran, mengadakan pengamatan pembelajaran untuk meningkatkan kualitas pembelajaran, mengadakan pertemuan individual secara profesional dengan guru untuk meningkatkan profesi guru, meluangkan waktu dan memberikan bantuan bagi guru secara profesional dalam menyelesaikan persoalan dalam proses pembelajaran, memberikan support dan keadaan yang mendukung bagi guru dalam pembaruan dan peningkatan kualitas pembelajaran, melaksanakan pengembangan staf yang berencana dan terarah, melaksanakan kerjasama dengan guru untuk mengevaluasi hasil belajar secara menyeluruh, menciptakan tim kerja yang dinamis dan profesional, dan menilai hasil belajar peserta didik secara menyeluruh. ${ }^{41}$

Terdapat beberapa faktor yang mempengaruhi keberhasilan supervisi. Yaitu: situasi dan kondisi masyarakat sekitar sekolah, besar kecilnya sekolah yang menjadi tanggung jawab kepala sekolah, tingkatan dan jenis sekolah, keadaan guru-guru dan pegawai pegawai yang tersedia, dan kecakapan dan keahlian kepala sekolah itu sendiri. ${ }^{42}$

Dengan demikian apabila kepala sekolah menjalankan prinsip-prinsip supervisi dengan baik, niscaya diharapkan setiap lembaga pendidikan Islam sedikit demi sedikit akan mengalami kemajuan dan perkembangan serta dapat mencapai tujuan pendidikan.

\footnotetext{
${ }^{39}$ Febriyanti, Peran Kepala Sekolah Sebagai Supervisor Dalam Meningkatkan Kualitas Pembelajaran di MA Patra Mandiri Plaju Palembang, Journal of Islamic Education Manajemen, Juni 2017, Vol. 3, No. 1, 60

${ }^{40}$ Mulyasa, Manajemen \& Kepemimpinan Kepala Sekolah, 215

${ }^{41}$ Hendarman, Revolusi Kinerja Kepala Sekolah, Cet.7, (Jakarta: Indeks, 2019), 21

${ }^{42}$ Hendarman dan Rohanim, Kepala Sekolah sebagai Manajer Teori dan Praktik, 47
} 


\section{Kepala Sekolah Sebagai Leader (Pemimpin)}

Kepala sekolah merupakan salah satu sumber daya manusia yang memiliki peran yang sangat penting dalam pengelolaan lembaga pendidikan Islam. Peningkatan kualitas pendidikan dan pengajaran, harus terus dilaksanakan dengan cara melakukan perbaikan-perbaikan. Hal ini merupakan tanggung jawab dan kewajiban kepala sekolah. Oleh karena itu, keadaan tersebut harus berdasarkan pada anggapan bahwa cita-cita utama dalam pelaksanaan pendidikan melalui sekolah adalah terwujudnya lingkungan sekolah yang kondusif agar tercipta proses pembelajaran yang menyenangkan. Peran kepemimpinan kepala sekolah tergantung pada kemampuannya dalam mempengaruhi lingkungan sekolah melalui proses pelaksanaan kepemimpinan yang dinamis. Dengan demikian, kepala sekolah merupakan seorang pemimpin pendidikan yang merencanakan, mengorganisasikan, mengkoordinasikan, mengawasi, dan merampungkan semua kegiatan pendidikan di sekolah dalam pencapaian tujuan pendidikan.

Kepala sekolah merupakan pemimpin pendidikan yang berperan meningkatkan kualitas pendidikan. Terciptanya semangat dan kerjasama yang harmonis, kemauan yang kuat dalam mengembangkan pendidikan, kondisi kerja yang mendukung dan perkembangan profesional di antara para guru, semua itu ditentukan oleh kualitas kepemimpinan kepala sekolah. Dengan demikian kepala sekolah merupakan kunci kesuksesan sekolah dalam mencapai tujuannya. ${ }^{43}$

Pada saat ini, banyak tuntutan masyarakat terhadap sekolah. Sekolah harus mampu memberikan layanan pembelajaran yang bermutu kepada siswanya. Oleh karena itu, untuk dapat memenuhi tuntutan tersebut, fungsi kepemimpinan kepala sekolah harus berfokus pada masalah pembelajaran. Dengan demikian, pembelajaran akan berkualitas jika kepala sekolah menjalankan fungsi sebagai manajer dan sebagai instructional leader. ${ }^{44}$

1. Kepala sekolah sebagai pencipta iklim kerja

Budaya dan iklim kerja yang mendukung dan memadai, akan menjadikan setiap guru lebih termotivasi dan bersemangat untuk meningkatkan kompetensinya dan menunjukkan kinerja nya secara unggul. Dalam upaya menciptakan budaya dan iklim kerja yang mendukung kepala sekolah hendaknya memperhatikan prinsip-prinsip sebagai berikut: kegiatan yang dilakukan oleh guru menarik dan menyenangkan, tujuan harus jelas dan guru ikut berpartisipasi

\footnotetext{
${ }^{43}$ Hendarman dan Rohanim, Kepala Sekolah sebagai Manajer Teori dan Praktik, 47-48

${ }^{44}$ Endang Herawan, Kinerja Kepala Sekolah Sebagai Instructional Leader, Pedagogia Jurnal Ilmu Pendidikan, 259

258 | IQ (Ilmu Al-qur'an): Jurnal Pendidikan Islam| Volume 3 No.02 2020
} 
merumuskan tujuan, guru mengetahui apa yang ia kerjakan, guru diberikan penghargaan, dan kebutuhan sosial psikologis guru harus terpenuhi sehingga memperoleh kepuasan. ${ }^{45}$

2. Kepala sekolah sebagai wirausahawan

Kepala sekolah sebagai wirausahawan yaitu kepala sekolah seharusnya menerapkan prinsip-prinsip kewirausahaan dihubungkan dengan peningkatan kompetensi guru sehingga dapat menciptakan pembaharuan, keunggulan komparatif, serta memanfaatkan berbagai peluang. Kepala sekolah dengan sikap kewirausahaan yang kuat akan berani melakukan perubahan-perubahan yang inovatif di sekolahnya, termasuk perubahan dalam hal-hal yang berhubungan dengan proses pembelajaran siswa dan kompetensi guru. ${ }^{46}$

3. Kepala sekolah sebagai inovator

Menurut Marno dalam Ushansyah Kepala sekolah sebagai inovator akan tercermin dari cara-cara ia melakukan pekerjaannya secara konstruktif, kreatif, delegatif, integratif, rasional dan obyektif, pragmatis, fleksibel, keteladanan, disiplin, serta felksibel. ${ }^{47}$

Selain 8 fungsi di atas, kepemimpinan kepala sekolah/madrasah dalam pengelolaan lembaga pendidikan Islam juga berfungsi untuk mentransformasikan nilai-nilai positif, baik terhadap pendidik maupun peserta didik. Seperti: kecerdasannya, wawasannya, pemikirannya, semangatnya, kedisiplinannya, kinerjanya, sikapnya, perilakunya, akhlaknya, atau secara umum kepribadiannya. Semua harus ditransformasikan dari kondisi yang negatif (kekurangan) menjadi positif, berpotensi, berkompetensi, berdaya pendorong/penyemangat, dan berdaya keteladanan. Transformasi tersebut terhadap pendidik sangatlah penting, karena pendidik merupakan ujung tombak keberhasilan peserta didik. ${ }^{48}$

Selanjutnya, Leadership (Kepemimpinan) dalam pengelolaan lembaga pendidikan Islam, harus melakukan percontohan sebagai berikut :

Pertama, mewujudkan sikap kerja yang professional. Sikap ini merupakan refleksi keahlian yang diperoleh melalui pendidikan atau latihan khusus. Sikap kerja professional tersebut harus dimiliki dan ditunjukan oleh semua lapisan pelaksana pendidikan Islam. Sikap kerja demikian tidak dimiliki setiap orang karena terdapat skill (keterampilan) khusus dari suatu pendidikan maupun Latihan kultural dan Latihan professional yang memadai.

Kedua, membudayakan pelayanan prima. Posisi dan fungsi pelayanan yang prima belakangan sangat strategis dan menentukan rasa simpati masyarakat dalam mendukung dan

\footnotetext{
${ }^{45}$ Hendarman dan Rohanim, Kepala Sekolah sebagai Manajer Teori dan Praktik, 48-49

${ }^{46}$ Hendarman dan Rohanim, Kepala Sekolah sebagai Manajer Teori dan Praktik, 49

47 Ushansyah, Kepemimpinan Lembaga Pendidikan Islam, Ittihad Jurnal Kopertais Wilayah XI Kalimantan Volume 14 No.26 Oktober 2016, 58

${ }^{48}$ Mujammil Qomar, Strategi Pendidikan Islam, (Jakarta: Penerbit Erlangga, 2013), 85
} 
menentukan pilihannya pada suatu lembaga Pendidikan. Oleh karena itu, paradigma yang bisa dijadikan pegangan bagi manajer Pendidikan Islam, baik kapasitasnya sebagai kepala madrasah, kepala sekolah, pengasuh/kiai pesantren, ketua jurusan, dekan, maupun rector adalah sebagai khadim al ummat (pelayan Ummat), yang berarti mereka harus memberikan pelayanan yang terbaik pada orang lain.

Ketiga, memperkokoh misi dan aksi sosial. Pendidikan Islam dan penerapan nilai-nilai sosial harus menciptakan hubungan yang interaktif. Pendidikan Islam seharsunya membawa dan menanamkan nilai-nilai sosial. Sedangkan upaya menerapkan nilai-nilai sosial di masyarakat mengandung pesan-pesan edukatif. Dengan demikian manajer harus berusaha memiliki dan mencanangkan misi sosial, kemudian menindaklanjuti dengan melakukan aksi sosial terutama dalam Lembaga Pendidikan Islam.

Keempat, mengembangkan fungsi pemberdayaan. Manajer seharusnya berkonsentrasi memfasilitasi terwujudnya pemberdayaan pada peserta didiknya, yaitu dari kondisi mereka yang serba kekurangan menjadi minimal serba berkecukupan. Di dalam lembaga pedidikan Islam, manajer diharapkan dapat berbuat banyak dalam menempuh langkah-langkah strategis mengawal transformasi kompetensi peserta didik.

Kelima, membangun atmosfer akademik. Manajer baik kepala sekolah/madrasah, rektor, dekan, ketua maupun direktur harus berusaha membangun atmosfer akademik di Lembaga pendidikan yang mereka pimpin masing-masing untuk membuktikan dan menunjukan kepada public bahwa mereka benar-benar menekankan dan mengutamakan bukan sekedar transmisi ilmu pengetahuan, lebih dari itu, mereka juga melakukan transformasi ilmu pengetahuan tersebut.

Keenam, mewujudkan prestasi yang berkesinambungan. Manajer harsu berusaha menjadikan lembaga pendidikan Islam yang dipimpinnya mampu menghasilkan prestasi ganda (prestasi akademik dan non akademik) secara berkesinambungan (terus-menerus).

Ketujuh, membudayakan perilaku utama. Lembaga pendidikan Islam senantiasa mengesankan pusat penanaman nilai-nilai Luhur atau nilai-nilai agama Islam. Dengan begitu manajer harus sadar dan berupaya membiasakan atau membudayakan perilaku utama pada seluruh jajaran yang terlibat dalam lembaga pendidikan Islam baik jajaran pemimpin, pendidik, tenaga kependidikan, tenaga non kependidikan, dan peserta didik.

Kedelapan, membudayakan keutamaan suasana. Suasana dalam lembaga pendidikan Islam ini menimbulkan penilaian sendiri dari masyarakat yang berkonsekuensi pada kelanjutan dan kemajuan lembaga pendidikan Islam. Selanjutnya manajer harus berusaha mencukupi 
fasilitas dasar dan harus berusaha menciptakan pola-pola kerja yang kolegian, kompak, harmonis, dan produktif untuk menopang proses pendidikan secara efektif dan efisien.

Kesembilan, membangun citra yang positif (positif image building). Manajer harus berusaha keras membangun citra yang baik di dalam maupun di luar. Manajer harus mengkomunikasikan dan menyebarkan informasi keutamaan, kelebihan atau prestasi lembaga pendidikan Islam yang dikelolanya kepada masyarakat luas. ${ }^{49}$

Demikianlah kepemimpinan (leadership) lembaga pendidikan Islam sebagai percontohan yang diharapkan, sehingga mampu mengangkat martabat lembaga pendidikan Islam di tengah-tengah masyarakat yang semakin heterogen dan pluralis.

\section{Kesimpulan}

Leadership (kepemimpinan) merupakan salah satu faktor yang menentukan pencapaian visi, misi, dan tujuan dari suatu lembaga atau organisasi. Dalam konteks lembaga pendidikan Islam, salah satu faktor kunci keberhasilan pengelolaan lembaga pendidikan Islam adalah kepemimpinan Direktorat Jendral Pendidikan Islam. Selain itu, kepala sekolah/madrasah, pengasuh pesantren, dekan, rektor, dan seluruh elemen pendidikan Islam. Dalam tulisan ini, terdapat 8 fungsi leadership dalam pengelolaan lembaga pendidikan Islam. Kepala sekolah/madrasah sebangai educator (pendidik), kepala sekolah/madrasah sebagai manajer, kepala sekolah/madrasah sebagai administrator, kepala sekolah/madrasah sebagai supervisor, kepala sekolah/madrasah sebagai leader (pemimpin), kepala sekolah/madrasah sebagai pencipta iklim kerja, kepala sekolah/madrasah sebagai wirausahawan, dan kepala sekolah/madrasah sebagai innovator. Selain 8 fungsi di atas, kepemimpinan kepala sekolah/madrasah dalam pengelolaan lembaga pendidikan Islam juga berfungsi untuk mentransformasikan nilai-nilai positif terhadap pendidik maupun peserta didik.

\section{Daftar Pustaka}

AB. Susanto. Stretegic Leadership. Jakarta: Gramedia Pustaka Utama. 2019.

Asnawir. Manajemen Pendidikan, Padang: IAIN IB Press. 2006.

Bush, Tony dan Derek Glover. School Leadership Concepts and Evidence, Spring: National College for School Leadership. 2003.

Bush, Tony. Educational leadership and management: theory, policy, and practice, South African Journal of Education Copyright EASA Vol 27(3) 2007,391-406

${ }^{49}$ Mujammil Qomar, Strategi Pendidikan Islam, 108-116 
Cuban L, The Managerial Imperative and the Practice of Leadership in Schools, Albany, NY: State University of New York Press, 1899.

Febriyanti. Peran Kepala Sekolah Sebagai Supervisor Dalam Meningkatkan Kualitas Pembelajaran di MA Patra Mandiri Plaju Palembang, Journal of Islamic Education Manajemen, Juni 2017, Vol. 3, No. 1.

Hafni Sahir, Syafrida, Mulkan Fadhli, Acai Sudirman, Abdurrozzaq Hasibuan, Dina Chamidah, Salmiah, Salmiah, Sherly, Sherly, Erika Revida, Janner Simarmata, Sukarman Purba. Keterampilan Manajerial Efektif. Sumatera Utara: Yayasan Kita Menulis, 2020.

Hendarman dan Rohanim. Kepala Sekolah segabai Manajer Teori dan Praktik. Bandung: PT. Remaja Rosdakarya, 2019.

Hendarman. Revolusi Kinerja Kepala Sekolah, Cet.7. Jakarta: Indeks. 2019.

Herawan, Endang. Kinerja Kepala Sekolah Sebagai Instructional Leader, Pedagogia Jurnal Ilmu Pendidikan. Vol 13 No.3 (2013).

Machali, Imam. Kepemimpinan Pendidikan dan Pembangunan Karakter, Yogyakarta: Pedagogia. 2012.

Marno, Triyo Suppriyatno. Manajemen dan Kepemimpinan Pendidikan Islam. Bandung: Refika Aditma. 2008.

Millah, Nur Ita A'ini Qudwatal, dan Far'ia. 2020. “Kepemimpinan Spiritual Dalam Lembaga Pendidikan: Analisis Maqasid Syariah”. Ilmu Al-Qur'an (IQ): Jurnal Pendidikan Islam 3 (01), 103-22. https://doi.org/10.37542/iq.v3i01.56

Mulyasa. Manajemen \& Kepemimpinan Kepala Sekolah. Jakarta: PT Bumi Aksara. 2013.

Qomar, Mujammil. Strategi Pendidikan Islam. Jakarta: Penerbit Erlangga. 2013.

Rahmi, Elvi. Leadership-Manajerialship dalam Pendidikan Islam, Jurnal Tadris, Volume. 13, Nomor 2, Desember 2018

Sagala, Syaiful. Pendekatan dan Model Kepemimpinan. Jakarta: Prenada Media, 2018.

Sepriadi dan Syarwani Ahmad. Pengaruh Peran Kepala Sekolah sebagai Supervisor Akademik Terhadap Kinerja Guru di SMK PGRI Tanjung Raja, Jurnal Manajemen, Kepemimpinan, dan Supervisi Pendidikan, Volume 2, No. 1, Januari-Juni 2017.

Syafar, Djunawir. Teori Kepemimpinan dalam Lembaga Pendidikan Islam. TADBIR : Jurnal Manajemen Pendidikan Islam, Volume 5, Nomor 1 : Februari 2017.

Ulum, M. Chazienul. Leadership Dinamika Teori Pendekatan dan Isu Strategis Kepemimpinan di Sektor Public. Malang: Universitas Brawijaya Press. 2012. 
Fungsi Leadership dalam Pengelolaan Lembaga Pendidikan Islam

Ushansyah. Kepemimpinan Lembaga Pendidikan Islam, Ittihad Jurnal Kopertais Wilayah XI Kalimantan Volume 14 No.26 Oktober 2016.

Powley, Roger and Cindy Edwards. Principles of Managmen. Commonwealth of Learning Edition 1.0. Burnaby: British Columbia. 2012.

R Terry, George. Prinsip-Prinsip Manajemen. Jakarta : Bumi Aksara. 2012.

E. Tarigan, Riswan. (2018). diakses dari https://huxleyi.wordpress.com/2018/12/07/brainyquote-a-leader-is-one-who-knows-the-way-goes-the-way-and-shows-the-way-john-cmaxwell-001/. 
Nur Fauziah

264 | IQ (Ilmu Al-qur'an): Jurnal Pendidikan Islam| Volume 3 No.02 2020 